\title{
PAST, PRESENT, AND FUTURE PERSPECTIVES ON GLASS CEILING APPLICATIONS IN HISTORIC BUILDINGS: CASES FROM ANKARA, TURKEY
}

\author{
GÜLŞEN DİŞLİ \\ Necmettin Erbakan University, Turkey
}

\begin{abstract}
In Turkey, stained and/or plain/colourless glass ceiling technology in historic buildings were used intensively, especially in early Republican Period of 1920s, and this technology is now approaching its 100th anniversary. In those years, both foreign and local architects designed and constructed public and civic buildings with stained or plain glass ceilings, mostly in the First National Architectural Movement Style or in modern international style. Yet, though there is a vast amount of research on those historic buildings, their glass ceilings have not been investigated and hence require a thorough examination. Thus, only with proper knowledge will this important historic feature hand down the next generations another 100 years. This research uses a case study approach by examining eight case study buildings: all have stained or plain glass ceilings constructed in 1926-1941 and all are located in historic parts of Ankara. It is considered important to document and preserve any glass ceiling application surviving from those periods. In this study, no significant differences were found in terms of the place of use, structure, and style of glass ceiling applications in case study buildings, no matter whether they were designed by a foreign or local architect, which confirms the reality of acculturation among the designers. The research also showed that the examined buildings all continue to be used in, or similar to, their original function, and their glass ceilings are mostly in good condition without any structural problem, yet require periodic cleaning in order to exhibit their decorations and integrity much more clearly and efficiently.
\end{abstract}

Keywords: historic buildings, stained glass, ceiling, Ankara, Turkey, First National Architectural Movement Style, radical modernization.

\section{INTRODUCTION}

The study is based mostly on case study approach from Ankara. However, rather than reflecting single case study experiences, the research covers broader theoretical issues in architectural planning, such as the role of foreign or local designers of the case study buildings, the role of built date in early or later periods of Republican Era, the various locations of glass ceilings inside the case study buildings, and their material, workmanship, form, and style. Thus, different from the existing literature, it is aimed to compare the similarities and differences of case studies in terms of their glass ceilings according to the mentioned parameters, an important architectural feature of the period, yet have not been worked before. In addition, this research examines questions of how the architects affected each other and whether acculturation existed among them in their designs of glass ceilings, and the effects of modernization will also be questioned. At the beginning of the 20th century, especially in 1908-1918 and continued up till 1930s a new architectural style called First National Architectural Style/National Architectural Renaissance, emerged in Turkey, symbolizing the ideological aspirations and cultural complexity of the late Ottoman Empire. The main objective of this style was to combine the decorations and architectural elements of Seljuk and Ottoman architecture with the new construction techniques of the period (concrete, iron, steel) [1]. Building designs including the essence of Turkish nationalistic architectural style, taking its roots from the historic association especially from the Ottoman Period, started with the Ottoman Bank and Düyun-u Umumiye Building 
designs of French Architect Alexandre Vallaury [2]. First examples of glass ceilings over the main halls of the buildings in late Ottoman period were also given by him, and continued with two Turkish architects Kemalletin Bey and Vedat Tek, both of whom were educated in architecture in Europe [2]. Giulio Mongeri, an Italian based Levantine architect, similarly, continued this tradition of glass-steel ceilings in his bank building designs, and highly contributed to the construction activities in Ankara [2]. At the same time, he gave lectures on architecture at Academy of Fine Art, thus trained many Turkish architects of the period such as Arif Hikmet Koyunoğlu and Şevki Balmumcu [3]. Modernization developments in Turkey started at the second half of the 19th century, and with the proclamation of the Republic in 1923, modernization projects of Turkey and the meaning of spatial organizations underwent important character variations [4]. New public buildings such as banks, hotels, train stations, post offices were constructed at the city centres following the institutionalization of the State [4]. Tekeli called the period of 1923-1950 starting from the beginning of the Republic up till the end of the Second World War as radical modernization process [4]. In this new architectural style, rationalist and functionalist principles of European modernization were adopted, aiming to design buildings similar to European examples [1]. Within this period, 1927-1940 is called as international style/new architectural style [5]. In this new style in Turkey, decorative components in architecture were rejected, the architecture was purified from all unnecessary ornamentations, and simple, plain surface and space arrangements were adopted [5]. Aslanoğlu [6] further divides the period 1932-1938 into three different subgroups as international style, neo-classical style, and the commencement of the second national architectural style according to various architectural characteristics and applications of local architects based on western counterparts. Clemens Holzmeister, Ernst Egli, Şevki Balmumcu, and Seyfi Arkan were among the architects in Turkey adopting the international style, by designing important civic buildings [7]. Usage of iron and steel in historic buildings as part structural frame system goes back to the end of the 18th century. Ditherington Flax Mill, a product of Industrial Revolution, in Shrewsbury, England is considered to be the first iron-framed building in the world built in 1796 [8]. In The Crystal Palace, built in 1850, in Hyde Park, London, on the other hand, cast-iron and plate-glass were used together, all produced industrially and in a standardized way [8]. Transparency, lightness, and flexibility are important features of steel-glass systems.

\section{MATERIAL AND METHODS}

In this research, a case study approach is adopted. The focus of this case study research was on eight historic buildings (five banks, a train station, a faculty building, and a hotel) dated to 1926-1941, and located in Ulus and Cebeci, Ankara. The particular cases were chosen because they have/had original glass ceilings with minor interventions only and reflecting the architectural style of the period designed by both foreign and local architects. Yet, the buildings that had glass ceilings but no more existent today or as later additions, and the ones known to have original glass ceilings with little or no data on are excluded from the main part of the research. In order to get information on the glass ceilings of case study buildings, in addition to site visits for observations, historic, archival, and literature survey have also been conducted, including the archives of General Directorate of Foundations, Goethe Institute online archive, and official web sites of the institutions. 


\subsection{Case study buildings}

To illuminate the various types of glass ceilings in historic buildings built during the first twenty years of Republican period in historic centres of Ankara, first, basic information has been given on the case studies in following sub-headings. They were examined under specific headings as stained glass ceilings and plain glass ceilings.

\subsubsection{Stained glass ceilings: Ziraat Bank Building}

Ziraat Bank Building was designed by the architect, Giulio Mongeri, in Early Republican Period, and in The First National Architectural Movement Style. Ziraat Bank, as one of the early works of Mongeri, was built in 1926-1929, in Ulus. It has a large, high, rectangular entrance hall, and its stained glass ceiling is located over this space. Today, this part is used as a museum. The ceiling has a grid layout consisting of in total $8 \times 19$ square plates constituting a rectangular ceiling. Each square plate has been divided further by thinner steel bars into $3 \times 3$, in total 9 smaller grids. Namely, glass and steel bars form the structure of the stained glass ceiling. In terms of artistic style, the coloured decoration at the centre of the ceiling has a Baroque impact [9]. There are grain bundles/wheatear symbolizing the fertility and abundance at the very centre and fruit basket decorations on its both sides. The borders of the glass ceiling have European floral motives [3]. Coloured decorations have been used intensively at the centre. There are also coloured glasses at the borders. On the other hand, the remaining parts are made of plain glass (Fig. 1).
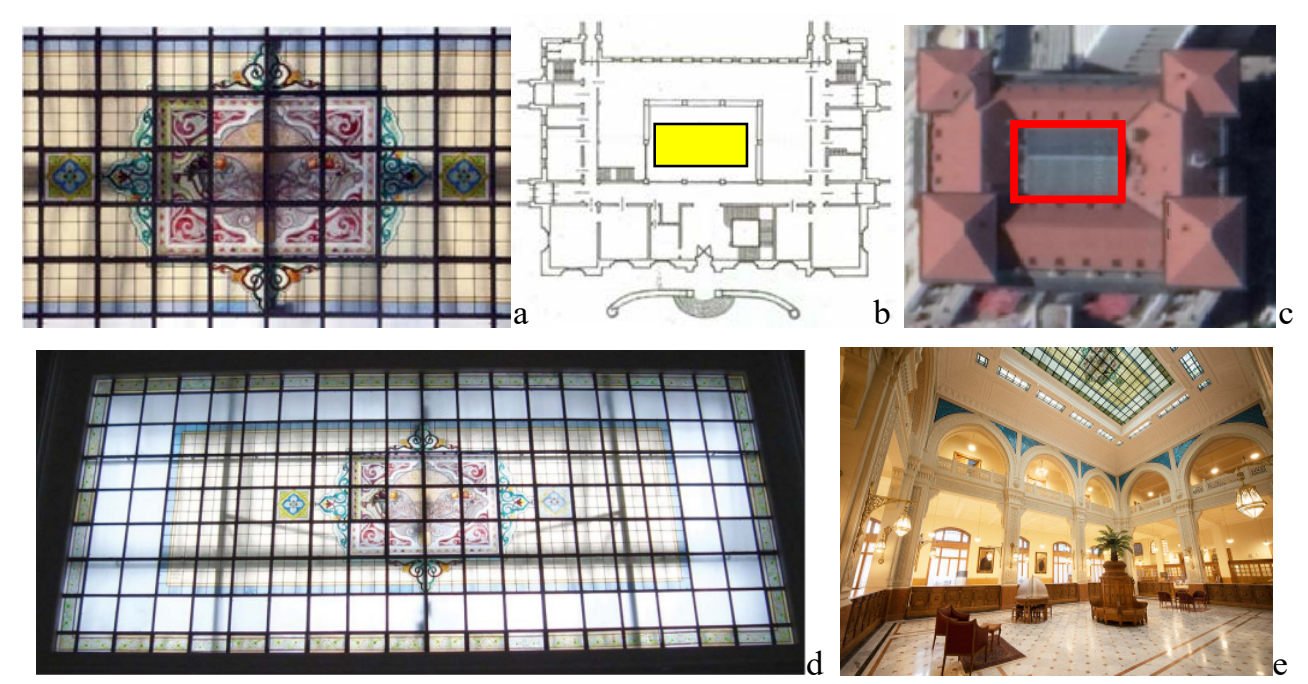

Figure 1: Ziraat Bank stained glass ceiling decorations at the center of the main hall (a, d, e), its drawing plan (b), and top roof view (c). (Sources: Akdăg 2019, p. 89; Çinici 2015, p. 28; Aslanoğlu 2001, p. 242; https://earth.google.com/web/[10]; ziraatbank.com. $r$ [11].)

\subsubsection{Stained glass ceilings: The headquarters of Turkish Economy Bank Building}

The Headquarters of Turkish Economy Bank Building was designed, similarly, by Giulio Mongeri, an Italian based Levantine architect, in 1929 in historic area of Ulus. It follows the design style of First National Architectural Movement. It is a corner building entered 
via marble stairs. The building is re-functioned to be used as a museum in 2019. The building has a large, oval main hall/customer acceptance hall, covered with an elliptical stained glass ceiling. Thus, both this large hall and the corridors surrounding the gallery space on the above floors could be illuminated. On the stained glass ceiling, at the very centre, a human figure, who is the Greek god Hermes, the Roman equivalent being Mercury, has been depicted with his snaky wand in his hand and wings above his head and foot, representing his speed. Since Hermes is known to be associated with money and trade, his depiction might have been used over the main hall, considering the original function of the bank building [3]. On the borders of the stained glass ceiling, there are European style figural motives, similar to Ziraat Bank Building. Stained glasses of both buildings were brought from Corvaya-Bazzi\&C production firm based in Milano, Italy [3]. Except for the coloured and decorated parts, the remaining parts of the ceiling are made of plain glass. Again, similar to Ziraat Bank, the ceiling has a grid layout consisting of $3 \times 3$, in total nine smaller grids in each square plate, constituting an elliptical ceiling. This grid system is observable on both stained and plain glass plates, and each plate has been divided by steel bars. The ceiling is covered by plain glass at the roof level supported by steel trusses. There is also a wire mesh at the very top, to protect the ceiling and top cover from weather conditions and bird droppings (Fig. 2).

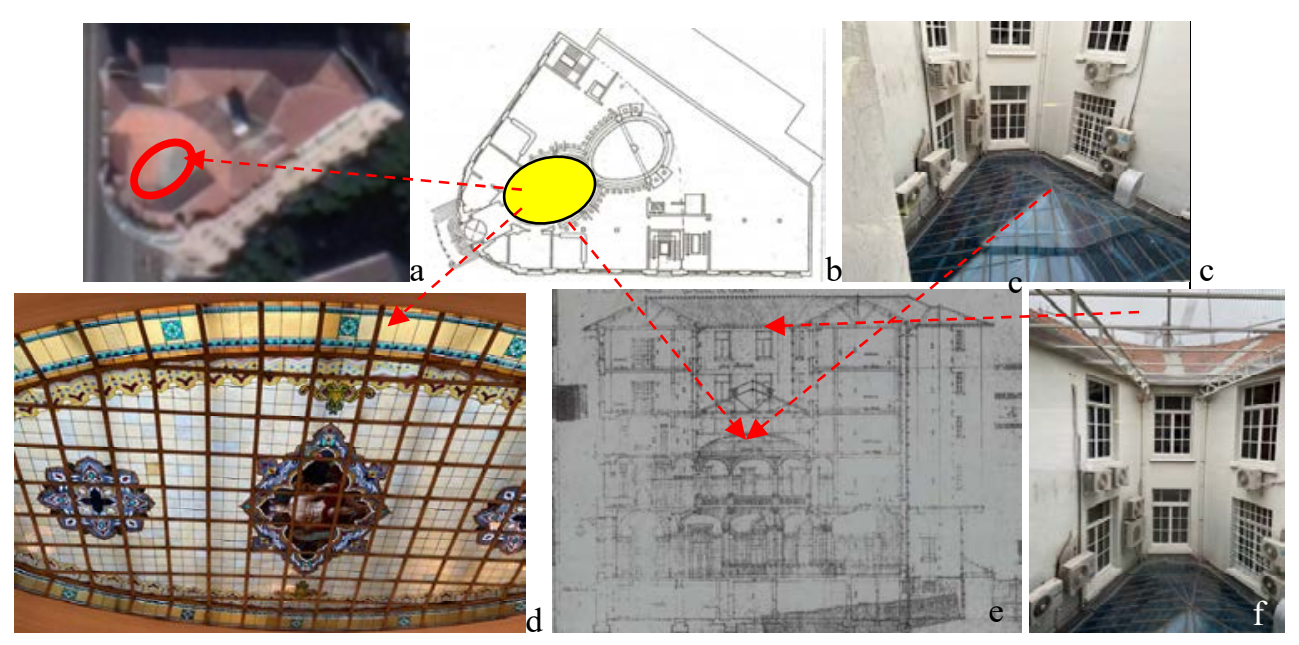

Figure 2: (a) A view from the top; (b) A drawing plan; (c) A second view of the top; (d) An interior view of the stained glass ceiling; (e) A section drawing; and (f) The wire mesh above the top very cover in the Turkish Economy Bank. (Source: Photo Archives of the Author, 2020 [12]; Aslanoğlu 2001, p. 248; Akşit 2010, p. 98; https://earth.google.com/web/[10].)

\subsubsection{Plain glass ceilings: Ankara Palas}

The Ankara Palas/Hotel Angora/Waqf Hotel, located on Cumhuriyet Boulevard, Ulus, was first constructed as a modern hotel building with a ball room, and continued to be used as a State Guest House in 1980 [13], [14]. It was first designed by Vedat Tek, and completed by the Architect Kemalettin in 1927 in the First National Architectural Movement Style, which characterizes a harmony of both western and traditional architectural features, taking its roots from the history and emphasizing the national characters [14]. Ankara Palas is a two 
storey building with an additional basement floor, and has a symmetrical plan type. It has a ball room at the very centre and the plaster-glass ceilings with decorated timber bars were covered above that central hall on its two sides. These original plaster-glass ceilings were dismantled during 1973 restoration interventions, and the steel-glass structure beneath the plaster decorations were exposed [15]. Similar to previous examples, each plate has 9 $(3 \times 3)$ smaller square pieces divided by thinner steel bars. Timber frame in between the square plates $(3 \times 8)$ is still in use (Fig. 3$)$.

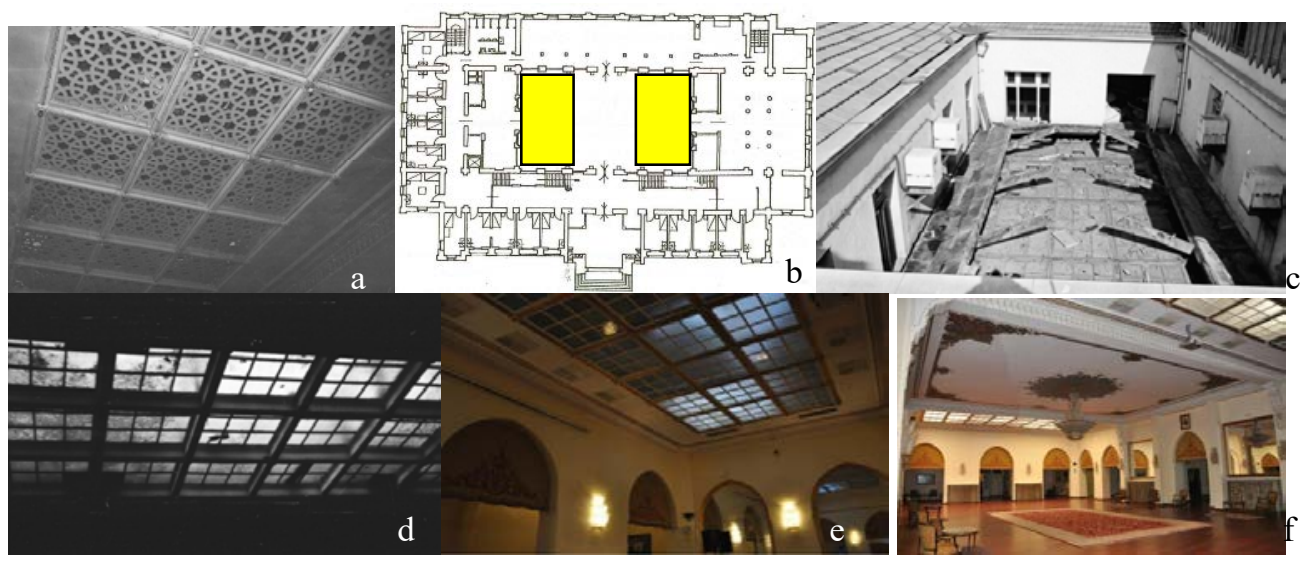

Figure 3: (a) View from the original plaster-glass ceiling above the Ballroom in Ankara Palas; (b) A drawing plan of the building; (c) Roof covering of the glass ceiling; (d) Glass ceiling after the restoration; and (e-f) Its current condition. (Sources: Archives of Directorate General of Foundations [15]; Aslanoğlu 2001, p. 270; Demir 2016, p. 124 [16]; ergir.com [17].)

\subsubsection{Plain glass ceilings: Ankara Central Train Station}

It was built in 1935-1937, designed in modern neo-classical style by the architect Şekip Akalın in symmetrical plan layout with a $12 \mathrm{~m}$-high central hall [6]. The glass ceiling is located over this central passenger lounge. Originally, the ceiling was constructed with plain opal glass divided by steel bars. The rectangular glass ceiling has a grid system of in total 15 square plates, three in one direction and five on the other way. Each plate is divided into $6 \times 6$, in total 36 small square pieces, and the whole load of the glass ceiling structure is carried by 6 steel roof trusses and beams ( $23 \mathrm{~m}$ in length) at the roof level covered by opal glass again. Today, the building maintains its original function, but the glass surfaces at the ceiling have been covered with a film coating depicting the picture of a cloudy sky including two trains and the logo of Turkey Republic State Railways at the centre (Fig. 4) [18].

\subsubsection{Plain glass ceilings: Ankara Central Bank Building}

Central Bank Building of Ankara was designed by an Austrian architect Clemens Holzmeister, in 1931-1933 in modern neo-classical style [6]. It was originally a four story building and later an additional one floor was added [6]. The building has a symmetrical plan type with a central hall and monumental entrance reached via stairs. The central hall of the building is illuminated by a glass ceiling, rectangular in shape. It is a plain glass ceiling divided into square plates (10 in one direction and 13 on the other side) without any colour 
or stained glass use. Each square plate is also divided into 4 equal pieces $(2 \times 2$ smaller square pieces). Steel bars are used in between the glass pieces for structural purpose. Above the ceiling there is a gable roof with rather a slight slope supported by steel cables on both sides (Fig. 5).

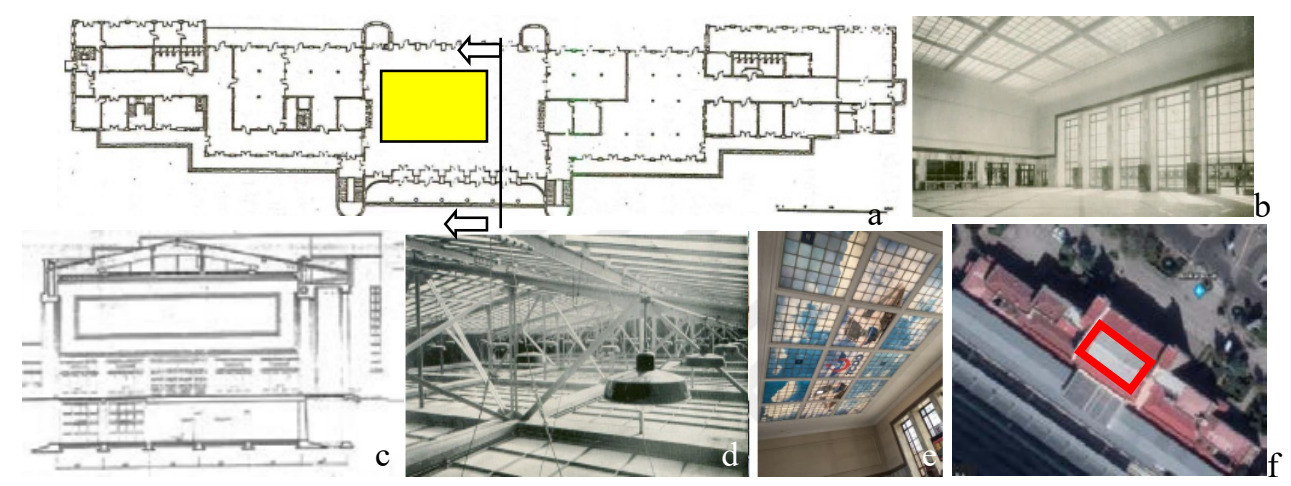

Figure 4: (a) Drawing plan of Ankara Central Train Station; (b) Its old photos showing the glass ceiling; (c) A section drawing; (d) Its roof construction-view (d, f); and (e-f) Its current condition. (Sources: Aslanoğlu 2001, p. 229; Cihangiroglu 2019, p. 86, 89, 242; [19]; https://earth.google.com/web/[10].)
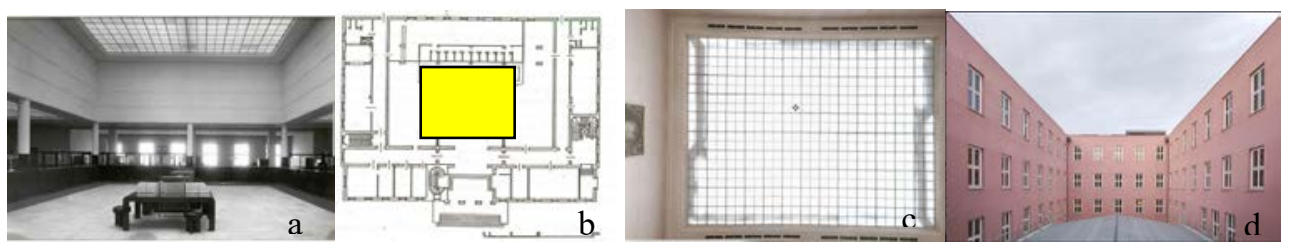

Figure 5: (a) An old photo of the glass ceiling in the Central Bank Building; (b) Its drawing plan; (c) Current condition of the ceiling; and (d) Its roof view. (Sources: Aslanoğlu 2001, p. 252; Online Archive of Goethe Institute [20]; paraanaliz.com [21].)

2.1.6 Plain glass ceilings: Ankara University Faculty of Law/Adliye Hukuk Mektebi It was designed by the architect Recai Akçay in 1938-1941 in modern neo-classical architectural style [5], [6]. The building, still maintaining its original education function, has two sections: on the front, there is the education and management section arranged around a closed courtyard, and at the back side, there are classrooms, a library, and other units. The central courtyard located on the south side of the entrance hall is closed with a glass ceiling, which is square in shape and divided into $9(3 \times 3)$ plates in total. Each plate is also divided into $16(4 \times 4)$ smaller square pieces. In the ceiling, both plain/colourless and coloured glass pieces have been harmonized all together (Fig. 6). Orange is preferred for the coloured pieces and they were organized in one row between each square plate, and in total there are two horizontal and two vertical coloured rows in between the plain glass plates. Steel bars are used for structural stability of the ceiling. 

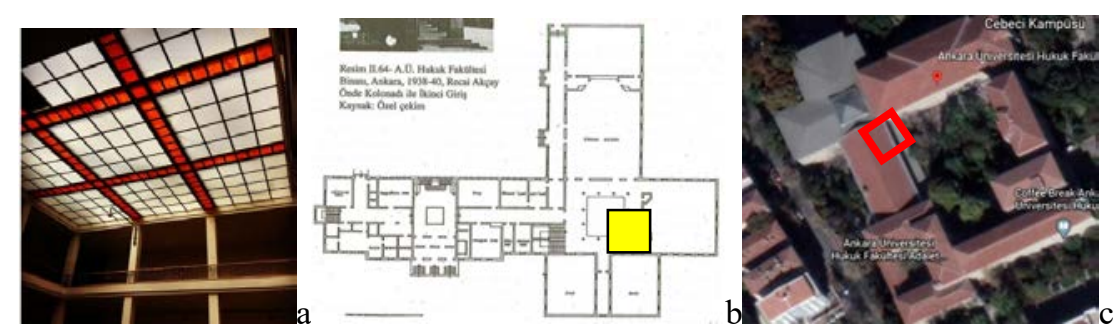

Figure 6: (a) A view from the glass ceiling; (b) Its drawing plan; and (c) A view of the roof. (Source: Aslanoğlu 2001, p. 191; law.ankara.edu.tr [22]; https://earth.google.com/web/ [10].)

2.1.7 Plain glass ceilings: The first Etibank Building/Directorate General of Foundations It was designed by the architect Sami Arsev in 1935-1936 in modern international architectural style [6]. The building, today used by Directorate General of Foundations, is formed by the combination of three different blocks. The glass ceiling is located above the first floor of the entrance block. It is composed of $3 \times 5$, in total 15 square plates with steel bars in between. Each plate has the same geometric decorations, including circular medallions and six-arm star motives, reminiscent of the decorations of Seljuk Period (Fig. 7).

\subsubsection{Plain glass ceilings: Divan-1 Muhasebat Building/Old Accountant Building}

It was first designed by the architect Nazim Bey in the First National Architectural Style and constructed by Arif Hikmet Koyunoğlu in 1924-1927. In 1930 its facades were redesigned by the architect Ernst Egli in modern architectural style [6]. It has a symmetrical plan, originally entered from the long façade facing to the Cumhuriyet Avenue. The entrance hall and the long corridors connected to it are covered with glass ceilings. There are in total three ceilings composed of $6 \times 14,14 \times 5,6 \times 14$ square plates divided with steel bars (Fig. 8). The square plates are not further divided into smaller square grids.

\subsubsection{Other historic buildings that have glass ceilings}

Historic buildings that had glass ceilings originally but lost these original ceilings for some reasons are listed under this heading. Ottoman Bank Building/Garanti Bank and Sergievi/Exhibition Hall/Opera House can be counted among those buildings. Ankara Mülkiye Mektebi/ Political Science Faculty Building (built date: 1936-1937, architect: Ernst Egli), is the other historic building in Ankara that has glass ceiling, but excluded from this research, since the glass ceiling over the terrace located on the large blocks is not the original design, but a later period addition [5], [6]. In Ottoman Bank (built date: 1926, architect: Giulio Mongeri), Aslanoğlu [6] mentions the existence of a glass ceiling divided into square pieces and hexagonal in shape above the narrow rentangular main hall of the bank. In original drawings of the building, this hexagonal ceiling is also observable [25], but it is not existent today [3]. In Sergievi/Exhibition Hall (built date: 1933-1935, architect: Şevki Balmumcu), similarly, there was a glass ceiling supported by steel trusses at the roof level, lying along the whole ceiling of exhibition hall (Fig. 9). Yet, during the transformation process of the building to be used as Opera House (1946-1948, architect: Paul Bonatz) [7], this glass ceiling was covered with suspended wooden ceiling. Therefore, today neither at the roof, nor at the ceiling, the traces of original glass ceiling are observable. 

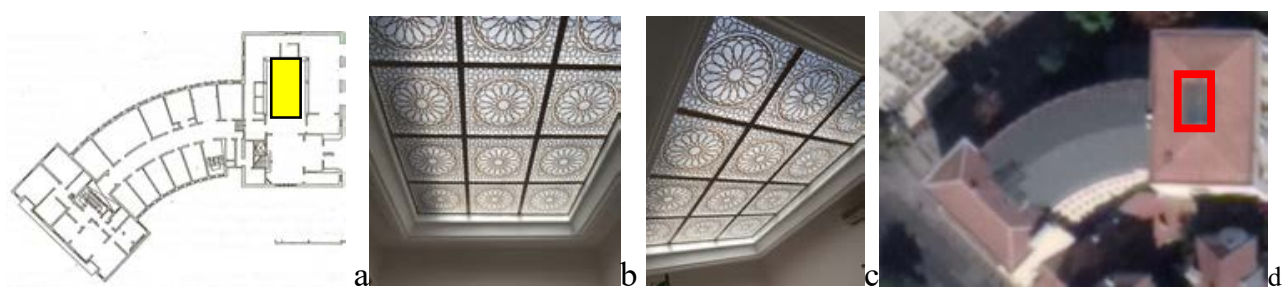

Figure 7: (a) Plan drawing of The First Etibank Building; (b-c) Views from its glass ceiling; and (d) Roof view. (Source: Aslanoğlu 2001, p. 256, Photo Archives of Zafer Gulbahar [23]; https://earth.google.com/web/ [10].)
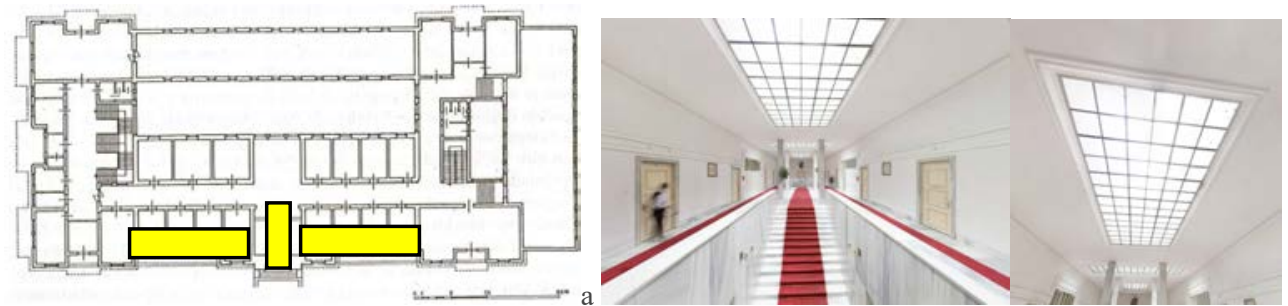

Figure 8: (a) Old Accountant Building plan drawing; and $(\mathrm{b}-\mathrm{c})$ Views from $\mathrm{c}$ glass ceilings. (Sources: Aslanoğlu 2001, p. 152; Online Archive of Goethe Institute [24].)
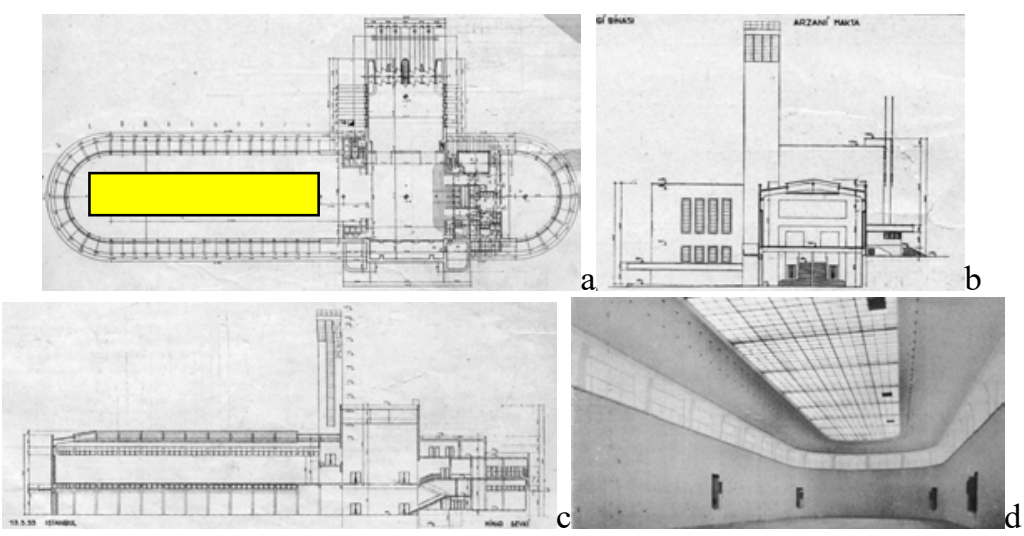

Figure 9: (a) Sergievi/Exhibition Hall original plan; (a) Section drawing; (b) Elevation drawing; and (d) A view from its glass ceiling over the exhibiton hall. (Source: Anonim 1933, p. 134-135, 137 [26]; Anonim 1935, p. 106 [27].)

In addition, 3rd Turkish Grand National Assembly Building (TBMM) (built date: 1938-1963, design: Clemens Holzmeister) is also categorized under this heading, since the glass plates, located above various spaces including western and eastern gateway of Honorary Hall [28] and above the first floor Group Assembly Rooms (southern side), are 
mostly in the form of filling elements in between the beams, positioned either in three or four-rows, intersecting each other. In ceiling of reception and ceremony hall there is also a small section of glass, where chandelier is located [6], [28]. Similarly, steel-glass ceiling above the inner central courtyard in Turkey Directorate General of Sugar Factory in Sihhiye (1954, architect: Paul Bonatz), and ceiling level glass windows at the elliptical dome skirts of Sumerbank Building (1937-1938, architect: Martin Elsaesser) are also excluded from the main part of the research (Fig. 10) [29].
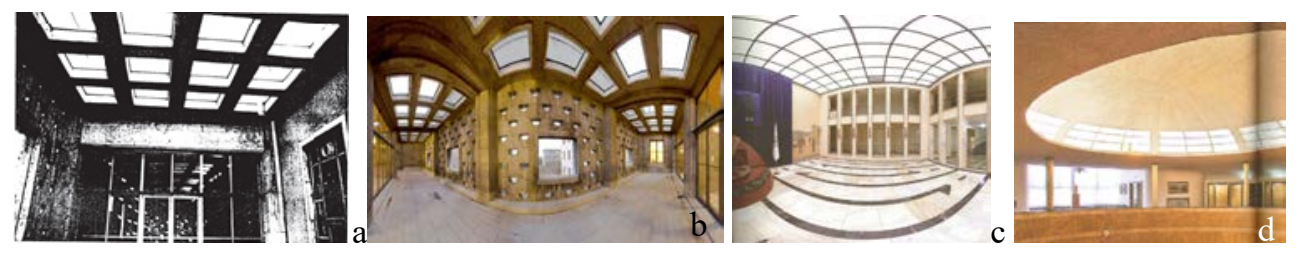

Figure 10: Turkish Grand National Assembly Building Group Assembly Hall. (a) First floor, southeren space; (b) Honorary Hall, western and eastern gateways; (c) Sugar Factory glass ceiling; and (d) Sumerbank. (Sources: Karsh Alpagut 1999, plate 68a; Online Archive of Goethe Institute [30]; Goethe-Institut Ankara 2011, p. 95, 204.)

\section{RESULTS AND DISCUSSIONS}

Results and evaluations of glass ceilings in case study buildings are as follows (Table 1):

- In three of the cases study bank buildings, namely the Central Bank, Turkish Economy Bank and Ziraat Bank, the stained glass and the plain glass ceilings have been located over the main (client acceptance) halls. In The First Etibank Building, on the other hand, the glass ceiling is observable on the first floor over the main hall opening to the working offices of the workers.

- In all case study buildings, except for The First Etibank Building and Old Accountant Building, no matter whether designed by a foreign or local architect, glass ceilings were designed in grid system. First, the ceilings were divided into larger plates, and then each plate was divided into smaller square pieces supported by steel bars: $2 \times 2$, $3 \times 3,4 \times 4$, or $6 \times 6$.

- Rectangle is the most common ceiling shape in case study buildings, yet in Turkish Economy Bank, glass ceiling is in elliptical shape, and in Faculty of Law, there is a square glass ceiling above the closed courtyard. In the Ottoman Bank, on the other hand, a hexagonal glass ceiling was used above the main hall [6].

- Among the case study buildings in Ziraat Bank and Turkish Economy Bank, both were the design of Giulio Mongeri, stained glass is observable with Baroque and Art Deco motives, namely include the European effects in their design. This situation might be explained with the National Architectural Movement Style that the architect Mongeri was a part, because one of the aims of this architectural movement was the representation of eclectic combinations. Mongeri, preferred to use glass and steel as modern new materials of the period in his designs. Ziraat Bank in Ankara has the largest glass-steel ceiling designed by him. In both Ziraat Bank and Turkish Economy Bank, the stained glass pieces of the ceilings were brought from an Italian firm and they both have European floral motives instead of Ottoman decorations. Yet, it is not 
known whether those motives were special admiration of the architect or were chosen among the already existing patterns/templates of the firm. Mongeri's use of European based components on the applications of First National Architectural Style designs might be because of the reflection of his western based education or because of his adoption of European architecture as his own history [3].

- Plain glass ceiling with or without coloured pieces, and formed in grid system is the most common ceiling type no matter whether designed by a foreign or local architect, which might be explained as an indicator of acculturation among the architects. It might be also explained as a result of the mutual education of foreign and local architects, such that in those periods, Turkish architects were educated in Europe, and foreign architects were a part of academia in Turkey [2], [3], [31].

- In all case study buildings glass and steel are the common materials in ceiling structures, some of which are supported by steel beams and trusses at the roof level, and as in Turkish Economy Bank wire mesh is also used at the very top level in order to preserve the glass ceiling and its structure from the weather conditions and bird droppings.

- Different from all other examples, in Ankara Palas, originally a plaster-timber frame glass ceiling was used, but during the restoration interventions in 1970s these original plaster pieces were dismantled and the steel-glass structure beneath these pieces were started to be used [15].

- In the Old Etibank Building, a different glass ceiling application is observable, such that, instead of smaller pieces of grid divisions, the whole ceiling is divided into $3 \times 5$, in total 15 equal plates and in each plate, geometric motives including circular medallions and six-arm stars are used as the main decoration forms.

- In all plain glass ceiling examples, colour use is not observable except for Law Building, in which orange colour pieces are located between the plain glass plates.

- Among the case study buildings in two of them, the glass ceilings are located in two or three different segments. In Ankara Palas, the glass ceilings are located on two sides of the ball room, and in Old Accountant Building there are three parts of glass ceilings lying through the whole corridor and at its very centre. In all other case studies, the ceilings are in one part, but include some grid subdivisions.

- The main case study buildings were either built in The First National Architectural Movement Style (1909-1930) or in Modern International Style (1930-1940). Stained glass ceiling application is observable only in earlier examples, namely in the ones (Ziraat Bank and Turkish Economy Bank) constructed in The First National Architectural Style. Plain glass ceiling application, on the other hand, is much more common and observable in both periods.

- There is no example with stained glass ceiling in modern international architectural style case studies, which might be because this period represents the plainness and simplicity in architecture and rejects any unnecessary decorations.

Regarding the conservation status of the glass ceilings in case studies: in Sergievi/Exhibition Hall and Ottoman Bank, the original ceilings are covered and can not be observed, in Central Train Station the original plain and colourless glass ceiling is covered with a film strip with a picture on it, and in Ankara Palas the original plaster decorations are not existent today. 
Table 1: Data on the glass ceilings of case study buildings. (1) Ziraat Bank; (2) Turkish Economy Bank; (3) Ankara Palas; (4) Old Accountant Building; (5) Ankara Central Train Station; (6) Ankara Central Bank; (7) Ankara University Faculty of Law; (8) The First Etibank Building.

\begin{tabular}{|c|c|c|c|c|c|c|c|}
\hline & \begin{tabular}{|l}
$\begin{array}{l}\text { Location of } \\
\text { ceiling }\end{array}$ \\
\end{tabular} & \begin{tabular}{|l|}
$\begin{array}{l}\text { Shape of } \\
\text { ceiling }\end{array}$ \\
\end{tabular} & $\begin{array}{l}\text { Material of } \\
\text { ceiling }\end{array}$ & Decoration & $\begin{array}{l}\text { No. of } \\
\text { plates }\end{array}$ & $\begin{array}{l}\text { No. of grid } \\
\text { pieces }\end{array}$ & \begin{tabular}{|l|} 
Conservation \\
status
\end{tabular} \\
\hline 1 & Central hall & Rectangular & \begin{tabular}{|l|}
$\begin{array}{l}\text { Steel-stained } \\
\text { glass }\end{array}$ \\
\end{tabular} & \begin{tabular}{|l|l|}
$\begin{array}{l}\text { Floral } \\
\text { motives }\end{array}$ \\
\end{tabular} & $8 \times 19$ & $\begin{array}{l}3 \times 3 \text { in each } \\
\text { plate }\end{array}$ & $\begin{array}{l}\text { In good } \\
\text { condition }\end{array}$ \\
\hline 2 & Central hall & Elliptical & \begin{tabular}{|l|}
$\begin{array}{l}\text { Steel-stained } \\
\text { glass }\end{array}$ \\
\end{tabular} & Baroque & - & $\begin{array}{l}3 \times 3 \text { in each } \\
\text { plate }\end{array}$ & \begin{tabular}{|l|}
$\begin{array}{l}\text { Recently } \\
\text { restored }\end{array}$ \\
\end{tabular} \\
\hline 3 & Ball room & Rectangular & $\begin{array}{l}\text { Timber-plain, } \\
\text { colourless } \\
\text { glass }\end{array}$ & $\begin{array}{l}\text { No } \\
\text { decoration }\end{array}$ & $\begin{array}{l}3 \times 8 \text {, in two } \\
\text { parts }\end{array}$ & $\begin{array}{l}3 \times 3 \text { in each } \\
\text { plate }\end{array}$ & $\begin{array}{l}\text { Under } \\
\text { restoration }\end{array}$ \\
\hline 4 & $\begin{array}{l}\text { Entrance hall } \\
\text { and along the } \\
\text { corridor }\end{array}$ & Rectangular & \begin{tabular}{|l}
$\begin{array}{l}\text { Steel-plain, } \\
\text { colourless } \\
\text { glass }\end{array}$ \\
\end{tabular} & $\begin{array}{l}\text { No } \\
\text { decoration }\end{array}$ & \begin{tabular}{|l|}
$6 \times 14,14 \times 5$, \\
$6 \times 14$ in \\
three parts \\
\end{tabular} & \begin{tabular}{|l|}
$\begin{array}{l}\text { No grid } \\
\text { division in } \\
\text { plates }\end{array}$ \\
\end{tabular} & $\begin{array}{l}\text { Closed at the } \\
\text { roof level }\end{array}$ \\
\hline 5 & Central hall & Rectangular & $\begin{array}{l}\text { Originally } \\
\text { Steel-plain, } \\
\text { colourless } \\
\text { glass }\end{array}$ & $\begin{array}{l}\text { Originally } \\
\text { no } \\
\text { decoration }\end{array}$ & $3 \times 5$ & $\begin{array}{l}6 \times 6 \text { in each } \\
\text { plate }\end{array}$ & $\begin{array}{l}\text { Covered } \\
\text { with a film } \\
\text { picture } \\
\text { above } \\
\end{array}$ \\
\hline 6 & Central hall & Rectangular & $\begin{array}{l}\text { Steel-plain, } \\
\text { colourless } \\
\text { glass }\end{array}$ & $\begin{array}{l}\text { No } \\
\text { decoration }\end{array}$ & $10 \times 13$ & $\begin{array}{l}2 \times 2 \text { in each } \\
\text { plate }\end{array}$ & $\begin{array}{l}\text { In good } \\
\text { condition }\end{array}$ \\
\hline 7 & $\begin{array}{l}\text { Above the } \\
\text { closed courtyard }\end{array}$ & Square & $\begin{array}{l}\text { Steel-plain } \\
\text { glass with } \\
\text { coloured pieces }\end{array}$ & $\begin{array}{l}\text { No } \\
\text { decoration }\end{array}$ & $3 \times 3$ & $\begin{array}{l}4 \times 4 \text { in each } \\
\text { plate }\end{array}$ & $\begin{array}{l}\text { In good } \\
\text { condition }\end{array}$ \\
\hline 8 & At the first floor & Rectangular & \begin{tabular}{|l}
$\begin{array}{l}\text { Steel-plain, } \\
\text { colourless } \\
\text { glass }\end{array}$ \\
\end{tabular} & $\begin{array}{l}\text { Geometric } \\
\text { decoration }\end{array}$ & $3 \times 5$ & $\begin{array}{l}\text { No pieces/no } \\
\text { grid system }\end{array}$ & Moderate \\
\hline
\end{tabular}

\section{CONCLUSIONS}

In this research, the glass ceilings of Republican period governmental buildings in Ankara, either designed by Turkish or foreign architects are presented and described in terms of their material, form, location in the building, decorations, and effects of the acculturation among the architects. Beneficial occupancy of foreign architects, engineers, and experts on art disciplines became the state policy with the Industrial Incentives Law of Turkey in 1927, and they started to work at the universities as educators and in state institutions [31]. In architecture discipline, Clemens Holzmeister (1927) and Ernst Egli (1927) were among the important Austrian and Swiss architects coming to Turkey just after the acceptance of the Law [31]. Giulio Mongeri, similarly, gave important contributions to the construction activities in Ankara in that period, especially in designing bank buildings. The foreign architects worked together with the Turkish counterparts especially in academia in their design and teaching activities. Regarding the glass ceilings in the buildings in Republican Period Ankara designed by both Turkish and foreign architects, the result was a ceiling which mostly uses a steel frame and glass pieces with or without coloured/stained pieces. Stained glass examples are observable in early periods of Republic, mostly with European decorations and designed by the same foreign architect. Grid system is applied in most of the ceiling structures either supported by steel or only in one example by timber frame systems. Whether the historic glass ceilings examined in this research might be considered as of outstanding importance in the development of roof lights in today's multi-storey buildings or not, the study is certainly an important part of architectural history giving light to this neglected area. As further studies, it is suggested to examine the extent of the role which this historic glass ceiling structures performed in the development of current roof 
lights in modern buildings, thus, their similarities, differences and existence of interaction between the past, present, and even future is suggested to be discussed.

\section{ACKNOWLEDGEMENTS}

The author would like to thank Gokce Gunel, for all his generous help during the provision of primary and secondary sources on the research area, Çetin Arslan, for his share of knowledge, and Zafer Gulbahar for his provision of photos of former Etibank Building.

\section{REFERENCES}

[1] Bozdoğan, S., Modernizm ve Ulusun Inşası, Erken Cumhuriyet Türkiyesi'nde Mimari Kültür, Metis Publishing: İstanbul, pp. 31, 175-176, 2002.

[2] Akşit, Ş.S., Ulusalcı Mimarlık ve Başkentte Finans Merkezi: Ankara İş Bankası Genel Müdürlüğ̈̈. Master's thesis, Gazi University, Ankara, 2010.

[3] Çinici, D., The biography of Giulio Mongeri, an architect active in building the capital city Ankara. Journal of Ankara Studies, 3(1), pp. 13-41, 2015.

[4] Tekeli, İ., Modernizm, Modernite ve Türkiye'nin Kent Planlama Tarihi, Tarih Vakfı Yurt Yayınları: İstanbul, pp. 95-110, 2009.

[5] Alpagut, L., Erken Cumhuriyet Dönemi'nde Ankara'daki Eğitim Yapıları. PhD dissertation, Hacettepe University, Ankara, 2005.

[6] Aslanoğlu, İ., Erken Cumhuriyet Dönemi Mimarlığı 1923-1938, METU Department of Architecture Publications: Ankara, pp. 29-252, 2001.

[7] Akpolat, M.S., Mimar Şevki Balmumcu'nun ve Ankara Sergievi Binası'nın üzüntü verici öyküsü. Kebikeç, 16, pp. 309-321, 2003.

[8] Marulyalı, Y., Çelik ve Mimarlık. Ege Mimarlık, 37(1), pp. 22-25, 2001.

[9] Akdağ, G., Ankara'daki 1. Ulusal Mimarlık Dönemi Banka Binalarında Cephe Düzeni ve Süsleme (1926-1929). Master's thesis, Gazi University, Ankara, 2019.

[10] Google Earth, Views of case study buildings. https://earth.google.com/web/. Accessed on: 13 Apr. 2020.

[11] Ziraat Bank Building. www.ziraatbank.com.tr/tr/bankamiz/kultur-sanat/ziraatbankasi-muzesi. Accessed on: 10 Apr. 2020.

[12] Photo Archives of the Author, Turkish Economy Bank/Museum, 2020.

[13] Aksoy, Z. \& Varol, Ç., Spatial transformation processes of immovable pious foundation properties from the early republic to today: Ankara case. Vakıflar Dergisi, 44, pp. 117-118, 2015.

[14] Sumbas, A., Türk Modernleşmesi'ni Ankara Palas Üzerinden Okumak: "Doğu'dan Batı'ya Açılan Bir Pencere. H.Ü. İktisadi Ve İdari Bilimler Fakültesi Dergisi, 31(1), pp. 171-198, 2013.

[15] Archives of Directorate General of Foundations, File on Ankara Palas, 2020.

[16] Demir, M., Ankara Palas. Master's thesis, Ankara University, 2016.

[17] Current condition of Ankara Palas ballroom. www.ergir.com/2012/Ankara_ Palas.htm. Accessed on: 10 Apr. 2020.

[18] Cihangiroğlu, M.S., Bellek Mekânlarının Değer Algısı ve Değişimi Üzerine Bir İnceleme: Ankara Tren Garı. Master's thesis, Hacettepe University, 2019.

[19] Aycı, M., Fotoğraflarla Yeni Ankara Garı 1937, TCDD: Ankara, 2006.

[20] Goethe Institute, Turkish Republic Central Bank Building. www.goethe.de/ins/tr/ank/ prj/urs/geb/ban/zen/trindex.htm. Accessed on: 10 Apr. 2020.

[21] Para Analiz. Turkish Republic Central Bank Building. www.paraanaliz.com/2016/ genel/merkez-bankasindan-85-yila-ozel-4-fotograf-3051/. Accessed on: 10 Apr. 2020 . 
[22] Ankara University Faculty of Law. www.law.ankara.edu.tr/fotograflarla-fakultemiz/. Accessed on: 10 Apr. 2020.

[23] Old Etibank Building, Photo Archives of Zafer Gulbahar, 2020.

[24] Goethe Institute, Old Accountant Building,/Eski Say1stay Binası. www.goethe.de/ins/ tr/ank/prj/urs/geb/res/kas/trindex.htm. Accessed on: 10 Apr. 2020.

[25] Ottoman Bank Ankara Branch Office Plan Drawings. https://archives.saltresearch.org/handle/123456789/3036. Accessed on: 10 Apr. 2020.

[26] Anonim, Sergievi Musabakasi-Ankara. Arkitekt, 5(29), pp. 131-153, 1933.

[27] Anonim, Sergi Evi - Ankara. Arkitekt, 4(52), pp. 97-107, 1935.

[28] Karslı Alpagut, L., Mimar Clemens Holzmeister ve III. Türkiye Büyük Millet Meclisi Binası. Master's Thesis, Hacettepe University, Ankara, 1999.

[29] Alpagut, L. \& Wagner, A. (eds), Bir Başkentin Oluşumu: Avusturyalı, Alman ve İsviçreli Mimarların Ankara'daki İzleri. Goethe-Institut Ankara: Ankara, pp. 95, 204, 2011.

[30] Türkiye Büyük Millet Meclisi Binas//Turkey Grand National Assembly Building. www.goethe.de/ins/tr/ank/prj/urs/geb/geb/par/trindex.htm. Accessed on: 10 Apr. 2020.

[31] Durukan Kopuz, A., Tracks of foreign architects of the early republic period in Turkey, Franz Hillinger sample. Megaron, 13(3), pp. 363-373, 2018. 